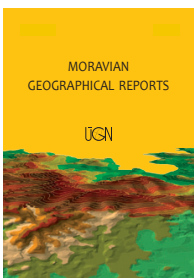

MORAVIAN GEOGRAPHICAL REPORTS

\title{
Impacts of natural hazards on an early industrial community: A case study of North Bohemia and its implications for long-term vulnerability assessment
}

\author{
Pavel RAŠKA ${ }^{a}$, Jakub DUBIŠAR ${ }^{b}$
}

\begin{abstract}
Regional databases of natural hazards and their social impacts have been increasingly established from documentary data to provide a rationale for the adoption of new disaster risk reduction strategies. This approach is extended in this article by pointing out factors that may underlie the changes in social vulnerability to natural hazards and that may cause non-homogeneities in long-term vulnerability assessments. We use the newly-established historical multi-hazard database for North Bohemia, based on a thorough search in a local newspaper. Altogether 275 records reporting 599 individual hazard events were analysed with respect to their relative direct social impact. Finally, we discuss the uncertainties resulting from the use of documentary data, and illustrate how long-term changes in social vulnerability are influenced by timedependent societal understanding of what is considered a hazard. This, in turn, accentuates the dynamics of cultural factors that should be considered when designing new risk reduction strategies.
\end{abstract}

Key words: natural hazards; vulnerability; documentary data; risk reduction, North Bohemia, Czech Republic

Article history: Received 30 August 2016; Accepted 1 March 2017; Published 31 March 2017

\section{Introduction}

Natural hazards represent a broad spectrum of disturbing events with potentially adverse impacts on society. Although the social impacts of and responses to hazard events have long been recognised, a rigorous approach to the social dimension of these phenomena was a relative latecomer to the research agenda. Following pioneering research by White (1936, 1942), human ecological approaches (Kates and Wohlwill, 1966; Burton et al., 1978; Hewitt, 1983), as well as developmental and structural approaches (Sen, 1981; Cutter, 1996), have led to a paradigmatic shift from hazardbased to vulnerability-based mitigation strategies (Sarewitz et al., 2003). Social vulnerability has become a central concept in assessing the potential impacts of natural hazards. Despite its varying definitions (Cutter, 1996; Adger, 2006; Hufschmidt, 2011; Lei et al., 2014), vulnerability can be generally expressed as a potential loss based on sensitivity and exposure to stress.

Among the questions central to vulnerability studies is the variations in human occupance of hazardous zones and approaches to adjust to risk in different geographical settings (Cutter, 1996). These research foci have brought new challenges in developing vulnerability mapping tools and, at the same time, have pointed to the influences that economic and societal development may have on vulnerability levels across countries (Wisner et al., 2004). On the other hand, the variability of vulnerability through time remains rather unclear, or as Cutter (1996, p. 534) noted "... the temporal dimension remains one of the least studied aspects of vulnerability".

\section{Theoretical departures and research aims}

\subsection{The temporal dimension of vulnerability}

Cutter and Finch (2008) analysed spatio-temporal changes in social vulnerability to natural hazards using the SoVI (Social Vulnerability Index) for the USA from 1960-2000, while Hufschmidt (2011) compared seven common vulnerability models, where the majority included the dimension of time. Most of the vulnerability models, however, were applied to society in a 'single' developmental stage and not in a broader historical perspective, which would enable consideration of the role societal learning has in risk reduction (Pfister, 2009). Such

\footnotetext{
${ }^{a}$ Department of Geography, Faculty of Science, J. E. Purkyně University in Ústí nad Labem, Czech Republic (*corresponding author: P. Raška, e-mail: pavel.raska@ujep.cz)

b The Municipality of Ústí nad Labem, Czech Republic
} 
learning may incrementally result in new risk reduction strategies but can also cause a paradigmatic shift toward new strategies when assumptions and principles of societal organisation change (see Bateson, 1972; Argyris and Schön, 1978; Voss and Wagner, 2010 for singleloop and double-loop learning). Finally, as a result of changing risk reduction strategies, we can assume that vulnerability may gain different meanings through time in terms of type of loss and entities affected.

The time-developmental constraints in vulnerability assessments are well illustrated in ongoing discussions of regional environmental change. The research agenda in the geosciences has introduced attempts to establish time-series of natural hazards derived from documentary data (Raška et al., 2014). This trend is most apparent in historical climatology and historical hydrology (e.g. Pfister et al., 2008; Brázdil, 2009; Glaser et al., 2010), but databases and timeseries of historical landslides have been established as well (e.g. Guzzetti et al., 1994; Ibsen and Brunsden, 1996; Klose et al., 2015; Raška et al., 2015). Although the databases and the time-series of natural hazards have been explored with respect to their social impacts, research in this domain is still not frequent (Dolák et al., 2015). In the study of social impacts from historical hazard events, emphasis has been mainly placed on three facets of the problem: reconstructing long-term variability in impacts at regional, national and international scales (e.g. Wanner et al., 2004; Dolák et al., 2015; Aceto et al., 2016); understanding vulnerability levels during extreme climatic periods (e.g. Pfister and Brázdil, 2006); and discussing the opportunities provided by historical experiences for current disaster risk reduction discourse (e.g. Raška and Brázdil, 2015).

The possible effects of learning (i.e. adoption of risk reduction strategies) on the homogeneity of long-term vulnerability assessments have been rather neglected. In particular, although methods to analyse relative direct impacts of natural hazards have been established (cf. Salvati et al., 2010; Caloiero et al., 2014), scarcely any attention has been devoted to the underlying conditions which influence long-term variability in vulnerability to natural hazards (e.g. Klose et al., 2016). Moreover, most studies have been oriented to the assessment of individual natural hazards, whereas the cumulative and cascading impacts of multiple hazards have not been studied extensively to date.

\subsection{Research aims}

In summary, from the above, while serious gaps in the historical treatment of vulnerability may be seen from a social science perspective, the geosciences, in turn, have been successful in completing long time-series but have paid only limited attention to the conditions underlying vulnerability. One primary motive of this paper, then, is to encourage further discussions about the links between geo-scientific and social scientific approaches to vulnerability. Although we see possible benefits for both sets of disciplines involved, our perspective in this paper stems from the experience of creating an historical multi-hazard database.

In particular, we argue that while there are notions of the availability, contents and limits of documentary data for historical disaster research in the geosciences, only limited attention has been devoted to the interpretative frameworks for these studies (e.g. Hufschmidt et al., 2005). For example, some established time-series have been analysed in terms of their statistical properties, showing the growing numbers of casualties and property damage for individual hazards through time, interpreted as a general increase in social vulnerability. The aim of this paper is to illustrate that such an approach is insufficient if researchers do not pay attention to the underlying social and technological factors of vulnerability, and such findings may, therefore, lead to misinterpretations of observed changes in vulnerability. In order to fulfil this objective, we use a newly-established database of natural hazards for the latter part of the $19^{\text {th }}$ century in North Bohemia (Czech Republic), which was based on a thorough search of local newspapers. The hazards are analysed in terms of their occurrence, social impacts and severity. Finally, we discuss the factors that influenced social vulnerability to natural hazards and how the changing nature of these factors may bias long-term vulnerability assessment.

\section{Material and methods}

\subsection{Case study area}

The study area is located in the northern part of the Czech Republic (Fig. 1; the area is ca. 2,500 $\mathrm{km}^{2}$ ) and is unique in its susceptibility to and frequency of various natural hazards in the context of Central Europe.

Landslides occur mainly on steep slopes with specific lithologies consisting of Neogene volcanites with weak layers of volcaniclastics and underlain by Mesozoic sandstones (Rybář et al., 2000). Localities with exposed sandstone rock walls in the Děčínská vrchovina Highland suffer from catastrophic rock-falls (Klimeš, 2011). The hydrological hazards are caused mainly by riverine floods of the Labe (Elbe) River (recent floods in 2002, 2006, 2010 and 2013: Brázdil et al., 2006) and flash floods on small water streams running from the Krušné hory Mts. in the North and from the volcanic terrain of the Česke středohoří Mts. in the South (Minářová et al., 2015; Raška and Brázdil, 2015). Due to long-term open-pit brown coal mining and extensive industry, the region is densely populated. The largest city of the region is Ústí nad Labem (Fig. 1), with a population of ca. 93,000 but the conurbation of the nine most populous cities in the study area (each of which is located less than $20 \mathrm{~km}$ from one another) has a total population of ca. 400,000 according to the 2011 census. Settlements are mainly concentrated in basin locations and in deeply eroded river valleys due to topographic suitability, which influences vulnerability to particular hazards (floods, landslides and rock-falls in the valleys, shallow landslides and subsidence near the mining sites).

\subsection{Building the catalogue}

The availability of accurate data on loss and damage outcomes associated with multiple hazards is fundamental for effective disaster risk management (Dilley and Grasso, 2016). Creating catalogues and databases of historical natural hazards, then, represents a necessary step in the assessment of long-term changes in natural hazard impacts. In many cases, relics or even proxy indicators of past natural hazards in urbanised areas have been erased or transformed by human activity (Raška et al., 2015), and documentary proxies often remain the only source of information. Although they are exploited extensively (e.g. Glade et al., 2001), critical attention must be paid to their interpretation in terms of both objective (e.g. availability and technical quality) and subjective (e.g. agenda setting, purpose of origin, and language style) factors that influence their content (Tropeano and Turconi, 2004). 

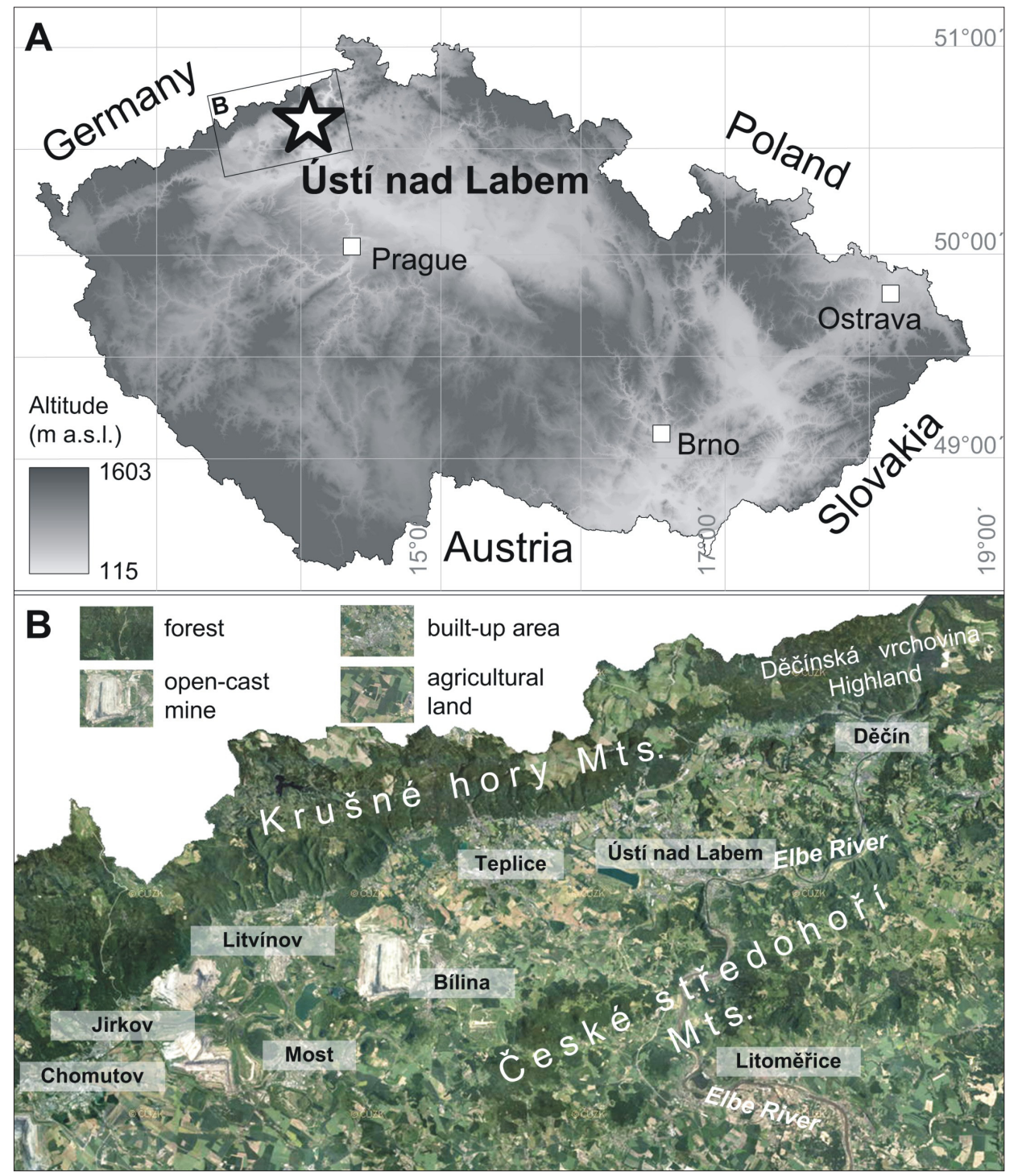

Fig. 1: Location of the study area: A - location of the study area with shaded DEM (digital elevation model) in the background; $B$ - major topographic features with land cover in the background and major settlements Source: authors' compilation

In this research, the local newspaper, Aussiger Anzeiger, available in a regional archive, was used as the main data source for the creation of the database of historical multihazards. This newspaper was selected as it represents the oldest periodical publication in the region and one of the oldest in the whole country. It was published in the German language during the years 1856-1902 with a periodicity of seven days (until 1873) and three days (from 1874), and printed in new gothic font (so-called Schwabach). The newspaper volume for 1871 is not preserved in the archive, and three other volumes are incomplete (eight months are missing for 1868, three months for 1872 and six months for 1900). The relevance of the source for natural hazard studies was validated during a previous survey (see Raška et al., 2015), which showed that local newspapers have (i) high sensitivity towards local events, (ii) a rapid publication process, and (iii) sufficient content related to social impacts of and responses to natural hazards.

The newspapers are not digitised, hence the extraction of information was based on manual searches using the key words listed in Table 1. The assignment of the described events to broader categories was carried out to reduce possible inaccuracies in the descriptions made by authors of the newspaper articles, while still keeping in mind possible nuances among the hazard types (e.g. floods and overflow). To assess the relation of various natural hazards and their combined impact on society, the database was designed as a multilevel catalogue. Each record consisted of a list of individual events, which were described in one or more articles. For example, if a torrential rain and a flood were described in the newspapers, they constituted one record consisting of two events. Each of these events might have been described in more subsequent articles; however, all of the articles were searched for reference to social impacts. This structure for the catalogue enabled assessment not only of the occurrence of the individual natural hazards (i.e. hazard events), but also their combination (i.e. record).

For each natural hazard event, the following information was recorded: hazard type, date, location, social impacts, and response. Social impacts were divided into the following categories: (i) fatality, (ii) damaged/affected building, (iii) damaged/affected lots, (iv) affected other property. These categories are certainly not complete, but they are considered as the major direct social impacts in disaster statistics (EEA, 2010; Dilley and Grasso, 2016), while indirect impacts may also include agricultural losses, road damage, etc. 


\begin{tabular}{llc}
\hline Natural hazard/related event & \multicolumn{1}{c}{ Original terms included } & Group \\
\hline Earthquake & Erdbeben, Erdschütterung & geological \\
Landslide & Erdrutschung, Rutschung, Erdsenkung, Schwimmsandeinbruch, & geological \\
& Schwimmsand, Erdeinbruch & geological \\
Rock-fall & Felssturz, Felsabsturz, Felsrutschung & hydrological \\
Flood & Hochwasser & hydrological \\
Overflow & Überschwemmung, Überfluten & meteorological \\
Rainstorm & Ungewitter, Gewitter & meteorological \\
Extreme rainfall & Wolkenbruch, Regen, Niederschlag, Regenguss, Gussregen, Platzregen, & \\
(torrential rain) & Gussregen, Regenwetter & meteorological \\
Lightning & Blitzschlag, Blitz & meteorological \\
Windstorm & Orkan, Sturmwind, Sturm & meteorological \\
Hailstorm & Hagel, Hagelwetter, Hagelstuck, Hagelschauer, Hagelschlag
\end{tabular}

Tab. 1: The original German terms used to describe various natural hazards in the Aussiger Anzeiger newspaper and assigned hazard group. Source: authors' compilation

(Bíl et al., 2014; Klose et al., 2016). In some cases, it was also possible to find supplementary information about the estimated financial losses.

\subsection{Data processing}

With regard to the multilevel character of the catalogue, data processing was performed at two levels. First, for the level of individual events (e.g. landslide, torrential rain, flood, etc.) in the newspapers, their temporal occurrence was evaluated using the indicators of frequency $(f)$ and recurrence $(r c)$ as follows:

$$
\begin{array}{ll}
\text { Frequency }(f) & f=\frac{H}{N} \\
\text { Recurrence }(r c) & r c=\frac{N}{H}
\end{array}
$$

where $N$ is number of years in the studied period and $H$ is number of hazard events.

While the two reciprocal indicators mentioned above are frequently used in time-series analyses, we also proposed a simple indicator for the time-regularity of individual events. This is because standard frequency indicators may be biased by the time-limited calamities of hazard events within the whole studied period. The regularity $(\mathrm{rg})$ indicator is designed as a standard deviation of intervals between individual consequent events:

$$
r g=\sqrt{\frac{1}{N} \times\left[\left(x_{1}-\bar{y}\right)^{2}+\left(x_{2}-\bar{y}\right)^{2}+\cdots+\left(x_{N}-\bar{y}\right)^{2}\right]}
$$

where $N$ is number of intervals between hazard events, $x$ is length of interval between two hazard events in years and $\bar{y}$ stands for average length of intervals between hazard events. The presence of a hazard event in the null year (i.e. 1855) was assumed, while the end of the period was calculated as the last occurrence of the hazard event.

The assessment of the social impacts of past natural hazards is always challenging because the documentary data does not include standardised records of impacts through time and for different hazard types. In this respect, the documentary records modify reality by constructing the severity of, and the agency and responsibility for, the event (cf. Brandström et al., 2008; Raška et al., 2014). Moreover, the availability of documentary data varies highly through time (Guzzetti et al., 1994), and therefore affects the reliability of any timeseries of social impacts. The assessment of social impacts in this study was based on a modified methodology proposed by Caloiero et al. (2014), which enables an assessment of relative direct impact. The method was applied both to individual events and to their combination. The impact score $\left(I_{\text {score }}\right)$ for an individual event (or their combination) is then calculated as a weighted ratio of its cumulative impacts and maximal recorded impacts:

$$
I_{\text {score }}=\left(\frac{F_{j}}{F_{\text {max }}}+\frac{\text { Bdam }_{j}}{\text { Bdam }_{\text {max }}}+\frac{\text { Ldam }_{j}}{\operatorname{Ldam}_{\text {max }}}+\frac{\text { OPaff }_{j}}{\text { OPaff }_{\text {max }}}\right) / 4
$$

where $F_{j}$ (Fatality), Bdam (Building damage), $\operatorname{Ldam}_{j}$ (Lot damage), and OPaff (Other property affected) are the values of the damage indicators for the hazard type or specific combination of hazard events, $j$, and $F_{\max }, B d a m_{\max }$, $L_{d a m_{\max }}$, OPaff $\max$ are the maximum values of the damage indicators.

The impact score gives an image of the cummulative severity of hazard events or their combination for the whole period. Along with it, we calculated an efficiency score $\left(E_{\text {score }}\right)$, which - depending on data availability - provides a clue for understanding the intensity of direct impacts from individual events:

$$
E_{\text {score }}=\left(\frac{\text { Bdam }_{j}}{\text { Baff }_{j}}+\frac{\operatorname{Ldam}_{j}}{\operatorname{Laff}_{j}}\right) / 2
$$

where $B_{d a m_{j}}$ (Building damage), $\operatorname{Ldam}_{j}$ (Lot damage), Baff (Building affected), and Laff $_{j}$ (Lot affected) are the indicators of damaged and affected buildings and lots by the hazard type or specific combination of hazard events.

\section{Results}

\subsection{The structure of the catalogue}

The search in the newspaper resulted in the creation of a catalogue with 275 records that occurred from 1856-1902, including 599 individual hazard events in 41 different combinations. A clear increasing trend may be seen from the time-plot of hazard event occurrence in Figure 2, which shows that meteorological hazard events are most frequent 


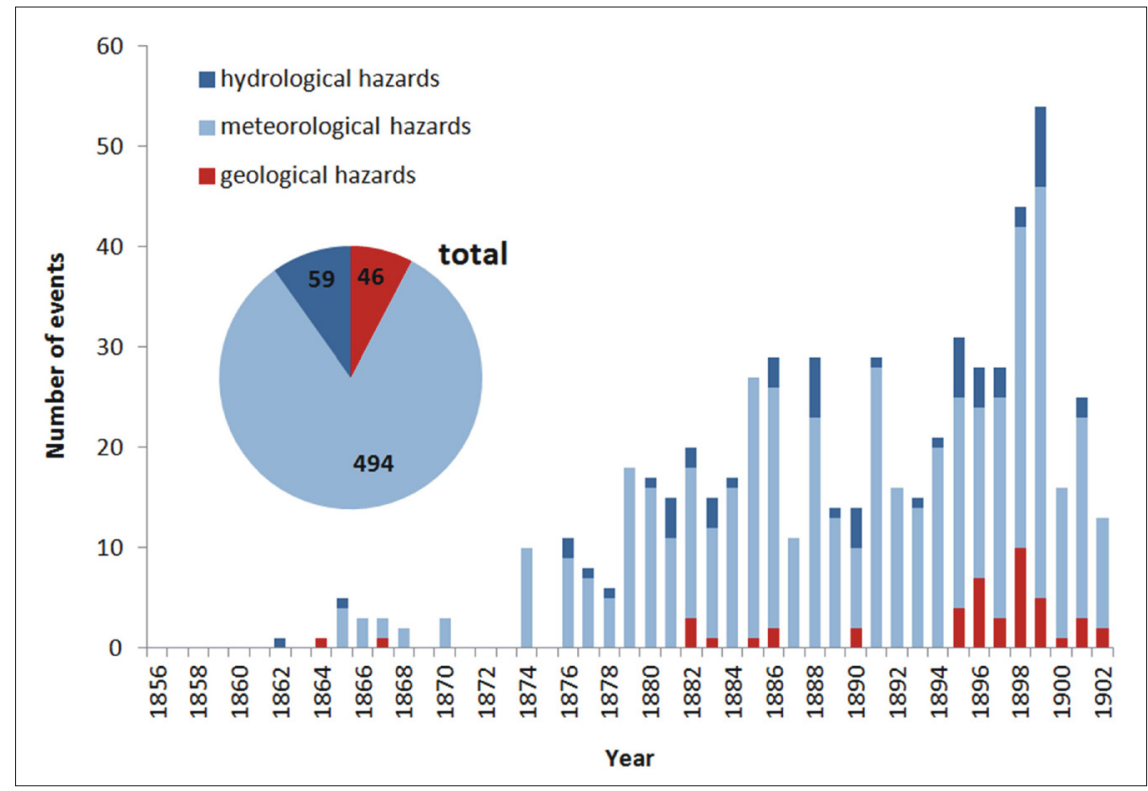

Fig. 2: Total number of hazardous events recorded (pie chart) and temporal occurrence of hazardous events in the studied period (bar chart), by hazard group (terminology from above Tab. 1)

Source: authors' calculations

in general (comprising $82.5 \%$ of the total), followed by hydrological $(9.8 \%)$ and geological $(7.7 \%)$ events. On the other hand, there are several cases of geological hazard events that were represented by more articles, which denote the social relevance of these events. For example, the landslide (and subsidence) in the town of Most on July 24, 1895, was reported in 21 consequent articles, and the landslide at Větruše hill in the municipality of Ústí nad Labem on August 26, 1899, was described in 17 articles. A similar extent of content description was found only for a limited number of hydrological hazard events, such as the flood in Ústí nad Labem in September, 1890, with 13 articles referring to flood and 22 to high water level.

\subsection{Temporal occurrence and triggers}

Temporal frequency was assessed by three indicators for three periods (Tab. 2), i.e. 1856-1902 (the whole period under study), and the sub-periods of 1856-1876 and 1877-1902, which denoted a change in editorial policy. The most frequent hazard events were meteorological (rainstorm, extreme rainfall, lightning, hailstorm), whereas geological hazard events were recorded only sporadically (e.g. only 3 cases of earthquakes). This results in a total recurrence of 0.28 years for rainstorm, for instance, and 15.33 years for earthquake. Considering the time-regularity of hazard events, rainstorms and lightning were the most regular during 1856-1902 with a standard deviation of event-free intervals of only 1.58 years. In contrast, $r g$ values for earthquakes and landslides were 17.72 and 7.85 years, respectively.

The occurrence of individual hazard events during the year is shown in Figure 3 and it is in agreement with the occurrence of triggers for particular hazards. The specific date (month and day) was not assigned in 14 cases and in two other cases the date was shown indirectly, referring to the 'last week' and to Christian calendar events. Among geological hazards, both landslides and rock-falls display slightly higher frequency during the late winter and spring months, resulting from freeze-thaw cycles (rock-falls) and from snow melt and precipitation totals that influenced the water saturation of soils and regolith. Hydrological

\begin{tabular}{cccccccccccc}
\hline Index & Period & EQ & LS & RF & FL & OF & RS & ER & LT & HS & WS \\
\hline Frequency (f) & $1856-1902$ & 0.07 & 0.67 & 0.26 & 0.78 & 0.50 & 3.57 & 2.33 & 3.13 & 1.15 & 0.57 \\
& $1856-1876$ & 0.00 & 0.00 & 0.10 & 0.15 & 0.05 & 0.65 & 0.15 & 0.65 & 0.05 & 0.15 \\
& $1877-1902$ & 0.12 & 1.19 & 0.38 & 1.27 & 0.85 & 5.81 & 4.00 & 5.04 & 2.00 & 0.88 \\
Recurrence (rc) & $1856-1902$ & 15.33 & 1.48 & 3.83 & 1.28 & 2.00 & 0.28 & 0.43 & 0.32 & 0.87 & 1.77 \\
& $1856-1876$ & n.a. & n.a. & 10.00 & 6.67 & 20.00 & 1.54 & 6.67 & 1.54 & 20.00 & 6.67 \\
& $1877-1902$ & 8.67 & 0.84 & 2.60 & 0.79 & 1.18 & 0.17 & 0.25 & 0.20 & 0.50 & 1.13 \\
Regularity (rg) & $1856-1902$ & 17.72 & 7.85 & 4.90 & 2.41 & 4.56 & 1.58 & 2.45 & 1.62 & 3.51 & 3.03 \\
& $1856-1876$ & n.a. & n.a. & 3.00 & 2.87 & n.a. & 3.00 & 2.87 & 3.09 & n.a. & 5.91 \\
& $1877-1902$ & 8.34 & 3.47 & 2.95 & 1.07 & 1.07 & 0.00 & 1.07 & 0.00 & 0.49 & 0.85 \\
\hline
\end{tabular}

Tab. 2: Indices of temporal occurrence of individual natural hazards and hazard-related events during the entire study period (grey) and two sub-periods (white). Legend: EQ - earthquake, LS - landslide, RF - rock-fall, FL - flood, $O F$ - overflow, $R S$ - rainstorm, ER - extreme rainfall, LT - lightning, HS - hailstorm, WS - windstorm, n.a. - data for calculation are not available

Source: authors' calculations 


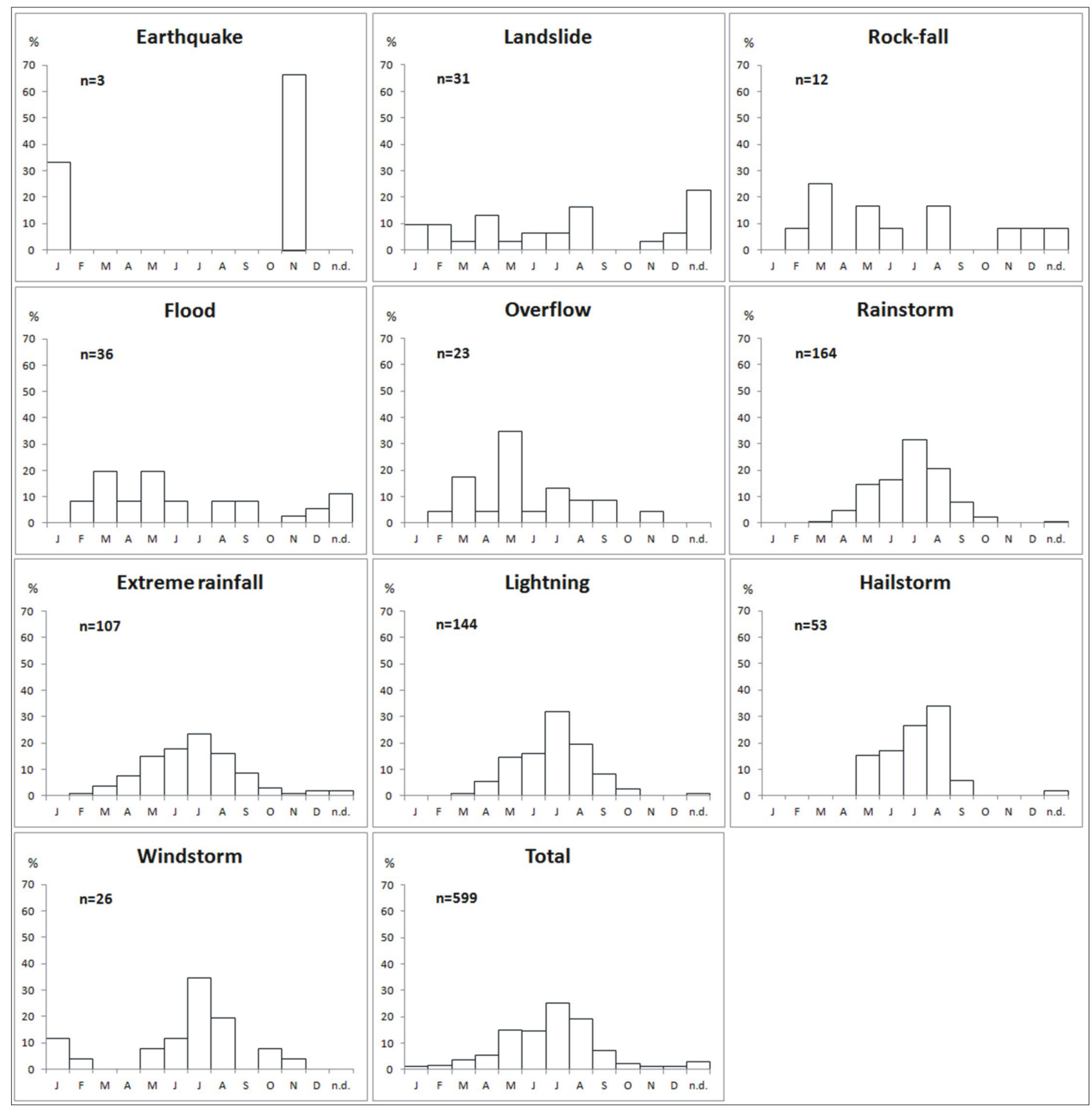

Fig. 3: The frequency of individual natural hazards and hazard-related events, by month over the entire studied period. Source: authors' calculations

Note: $n . d .=$ not dated events

hazards have two maxima that correspond to spring (snowmelt) and summer (torrential rains) sub-periods, which are typical for Central European hydrological regimes (cf. Brázdil, 2006). Meteorological hazard events displayed highest frequencies in the summer months, namely in July (rainstorm and extreme rainfalls, lightning and windstorm) and in August (hailstorm).

\subsection{Social impacts of natural hazards}

The studied natural hazards resulted in some extreme impacts on lives and property. Various hazards caused 42 fatalities in total, which is almost one fatality per year (Fig. 4). The most threatening hazards are the meteorological ones, followed equally by hydrological and geological hazards.

Table 3 and Figure 5 provide a more detailed view on the relative direct impacts caused by individual hazard events.
First, Table 3 enables the comparison of different hazard events in terms of their impacts $\left(I_{\text {score }}\right)$ and intensity of these impacts $\left(E_{\text {score }}\right)$. The highest values were obtained for rainstorms, present in 21 hazard combinations within 164 records and causing 31 fatalities and frequent losses of buildings, property and lots (mostly gardens), followed by lightning, which was present in 14 combinations within 144 records and causing 33 fatalities, but with lower impacts to property and lots. On the contrary, earthquake, rock-falls, floods and overflow scored lower in terms of their relative direct impacts. This needs a special explanation, particularly for floods. The study area experienced a catastrophic flood in 1890, which also affected large parts of the Czech Lands in the Vltava (Moldau) and Labe (Elbe) river catchments (cf. Brázdil, 2006; Brázdil et al., 2012). The reconstructed impact of this flood, however, is based on extent rather than on real expenses (see also the Discussion section, below). Moreover, the floods often affect 


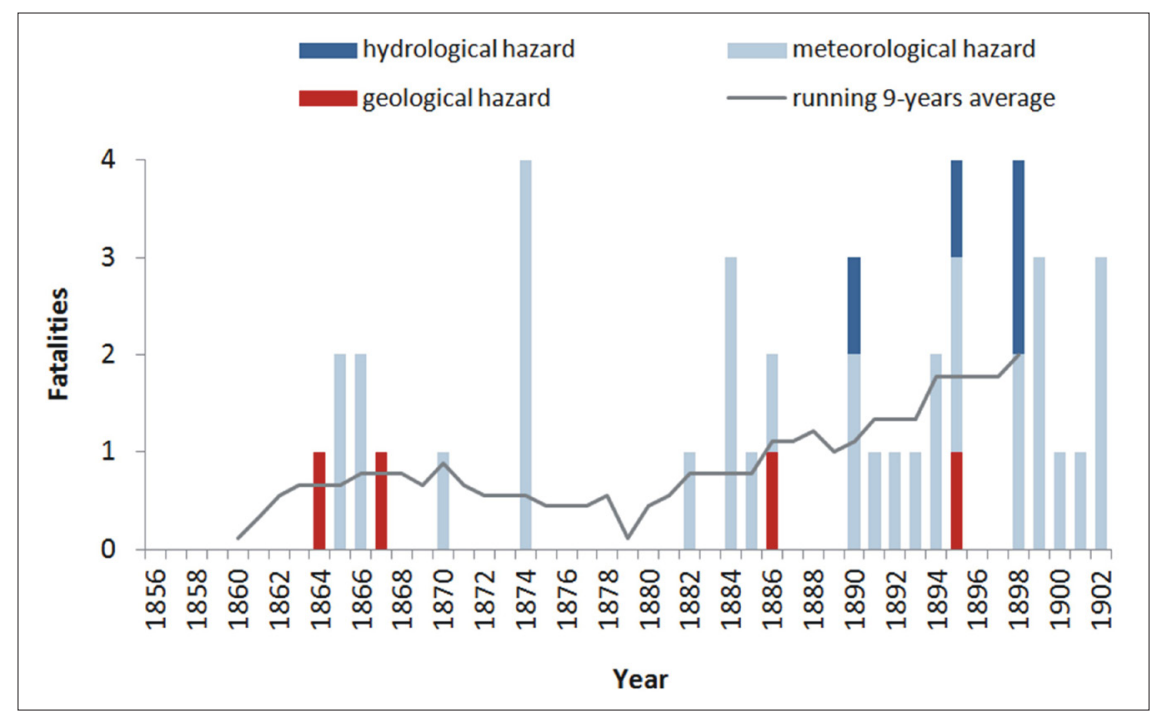

Fig. 4: Number of fatalities due to particular groups of natural hazards. The total number of fatalities over time is indicated as a 9-year running average. Source: authors' calculations

\begin{tabular}{lccrrrrrrrc}
\hline & Comb. & Records & F & Baff & Bdam & Laff & Ldam & OPaff & Iscore & Escore \\
\hline Earthquake & 2 & 3 & 0 & 2 & 1 & 0 & 0 & 2 & 0.01 & - \\
Landslide & 2 & 31 & 1 & 9 & 9 & 30 & 16 & 5 & 0.18 & 0.77 \\
Rock-fall & 2 & 12 & 3 & 3 & 3 & 3 & 2 & 2 & 0.06 & 0.83 \\
Flood & 6 & 36 & 4 & 9 & 4 & 11 & 4 & 6 & 0.10 & 0.40 \\
Overflow & 9 & 23 & 4 & 11 & 3 & 13 & 7 & 5 & 0.11 & 0.41 \\
Rainstorm & 21 & 164 & 31 & 110 & 61 & 37 & 34 & 62 & 0.97 & 0.74 \\
Extreme rainfall & 21 & 107 & 6 & 58 & 32 & 44 & 35 & 32 & 0.55 & 0.67 \\
Lightning & 14 & 144 & 33 & 112 & 62 & 18 & 17 & 61 & 0.87 & 0.75 \\
Hailstorm & 15 & 53 & 10 & 24 & 13 & 30 & 29 & 16 & 0.40 & 0.75 \\
Windstorm & 13 & 26 & 5 & 14 & 11 & 15 & 14 & 10 & 0.22 & 0.86 \\
\hline
\end{tabular}

Tab. 3: Frequencies of particular hazard events and their social impacts. Legend: Comb. - number of hazard combinations in which the hazard appeared; Records - number of records including the hazard event. Social impacts are shown as numbers of records with fatalities $(F)$, buildings affected $\left(B_{\text {aff }}\right)$, buildings damaged $\left(B_{\text {dam }}\right)$, lots affected $\left(L_{\text {aff }}\right)$, lots damaged $\left(L_{\text {dam }}\right)$ and other property affected $\left(O P_{\text {aff }}\right)$. For $I_{\text {score }}$ and $E_{\text {score }}($ impact and efficiency scores): see text. Source: compiled and calculated by authors

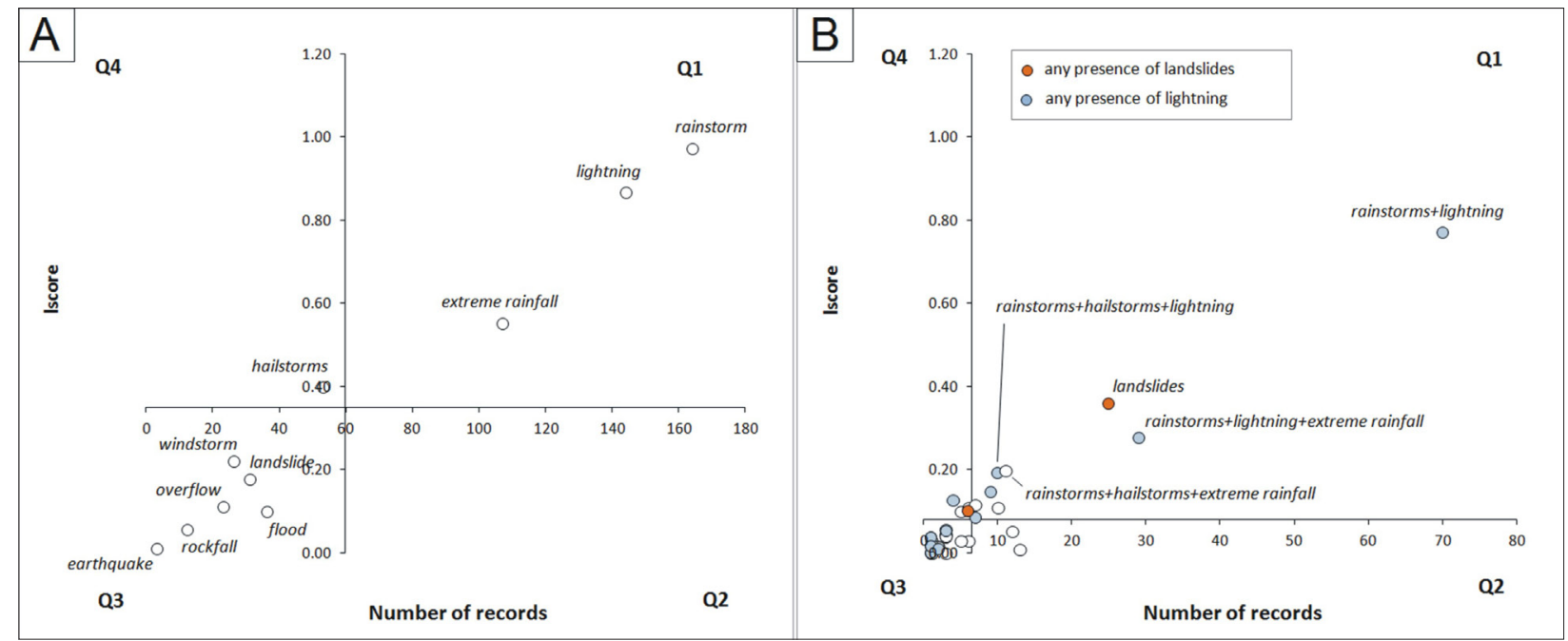

Fig. 5: Classification of events according to their relative direct impact at the level of: (A) individual hazard events; (B) recorded combinations of hazards. Legend: Quadrants Q1 - high frequency/high impact events; Q2 - high frequency/low impacts events; Q3 - low frequency/low impact events; Q4 - low frequency/high impacts events. Number of records $=$ number of records in which the combination or hazard type appeared. Impact score (Iscore): see text. Note: the origins of the axes are placed at the average values of the variables. Source: calculated by authors 
an extensive area and properties but do not necessarily damage or destroy the buildings, which stands in contrast to landslides or rock-falls, as illustrated by their $E_{\text {score }}$ values in Table 3 .

Finally, the combination of $I_{\text {score }}$ and frequency of the individual hazard events and their combinations, shown in Figure 5, allows for the consideration of social vulnerability to manifold natural hazards based on the threat they posed. The individual hazard events and their combinations are classified as four types by the quadrants in the diagrams:

1. Q1 - high frequency/high impact events;

2. Q2 - high frequency/low impacts events;

3. Q3 - low frequency/low impact events; and

4. Q4 - low frequency/high impacts events.

The assessment of individual hazard events in Figure 5A shows that three are classified as high frequency/high impact (rainstorm, lightning and extreme rainfall), whereas all others except hailstorms are classified as low frequency/ low impact events. Because the majority of hazard events that occur in combination are frequently of a causative nature (e.g. see temporal occurrence of hazard events during the year in Section 4.2), Figure $5 \mathrm{~B}$ provides a classification of combination hazard events. The resulting values confirm the frequency statistics and impact scores shown above. The most threatening combination of hazard events in terms of their impacts and frequency in the study period was rainstorm with lightning. The most threatening combinations of hazard events are those which include hailstorms and landslides, which are also located in Q1.

It must be noted, however, that frequency of hazards (or their combinations) and $I_{\text {score }}$ are related due to nature of the documentary data. First, the source data are originally narratives transformed into binary record (presence or absence of particular impact) for each type of the impact. Such transformation always results in uncertainties. Second, more frequent reference to social impacts may be caused equally by more frequent occurrence of these impacts, as well as by higher medial attention devoted to frequent hazards; thus adding further uncertainties to the database. Therefore, a quantitative temptation to provide the regression statistics between frequency and $I_{\text {score }}$ (or between any other indices) is a kind of misconception and would provide biased results (cf. Burke, 2005, p. 36-37).

\section{Discussion}

\subsection{Reliability of the dataset}

Based on this current research, we note the following two factors that may limit the reliability of datasets created from documentary proxies. First, it must be emphasised that any time-series reconstructed from documentary proxies does not directly relate to the occurrence of the natural hazards, but to their description in the analysed sources. While partly selfevident, this point is overlooked in the scholarly literature. Therefore, the results of the newspaper search constitute a time-series of articles (perhaps, a social reflection of hazard events) rather than a time-series of the events themselves. Although such a comment may be counter-posed by saying that the documentary record must reflect real events, the absence of any such reflection as well as possible duplicities in such reflections, results in uncertainties. With respect to duplicities, two types may occur: (i) two or more local reports may refer to one single event from different perspectives (e.g.
Elliott and Kirschbaum, 2007; Bíl et al., 2014), or (ii) two or more reports in sources with different territorial coverage may refer to one single event, which is known as the upscaling and down-scaling effect (e.g. Guzzetti et al., 1994; Raška et al., 2014).

Secondly, the combination of different sources (Raška et al., 2014) and agenda setting in sources with editorial boards and/or documents underpinned by political, economic or social goals, result in significant variations in the language style and structure (e.g. McCombs and Shaw, 1972; Brandström et al., 2008). Finding a standardized sequence of reports on social impacts and disaster relief is possible only in some cases (see for example, Raška and Brázdil, 2015, for a series of reports on historical disaster relief funding). Considering the lack of standardization in documentary records in terms of injuries, expenses or figures relating to damaged infrastructure, the social impacts of historical natural hazards may be evaluated on the basis of relative direct damage (Aceto et al., 2016). This enables comparisons between the severities of various natural hazards in terms of their aggregated social impacts, but does not refer to the costs of the damage. Therefore, some hazard events may rank lower than expected (e.g. the 1890 flood in this paper). The specification of costs would be possible by a complementary search in other documentary proxies (e.g. municipal reports or bills), but these are available only for the most disastrous events.

\subsection{Implications for long-term vulnerability assessment}

The aim of this paper was to present an empirical case study showing the limits arising from the assessment of long-term variations in social vulnerability to natural hazards. In this respect, it must be noted that social vulnerability to natural hazards is herein expressed as the severity of their social impacts. Certainly, this is a more generalised approach because it does not take into account different impacts of natural hazards across groups, for example for groups with varying demographic, economic or ethnic characteristics (Cutter, 1996), or for those with different capacities to cope with the impacts of hazards (Hewitt, 1983). On the other hand, it represents a pragmatic and valid concept when studying the impact of hazard events on historical communities because only scarce data may be found for social structure in historical statistics (the first modern census in the Czech Lands was in 1869), and explicit reports on disaster relief exist only for the most severe hazard events (e.g. financial collections, exhibitions and physical help after the 1890 flood in this study). If this approach is accepted, then the implications of the research results basically stem from two arguments.

Firstly, as explained in the preceding section, there is an argument that relates to the non-standardised nature of documentary proxies that do not permit building a reliable time-series of the social impacts of natural hazards. Moreover, the growing availability of sources through time results in an increase in the documented social impacts of natural hazards, and may result in higher observed vulnerability in terms of its absolute values. The second argument is that the long-term changes in the social impacts of natural hazards are underscored equally by a growing population's exposure to these events, the adoption of new risk reduction strategies (individual and organisational learning: Pfister, 2009), as well as by understanding what may even pose a hazard. All of these factors result in nonhomogeneities in any vulnerability time-series. To document 
these factors, Table 4 shows a simplified comparison of historical and current hazards, as referred to in this study and in current statistical reports.

Changing environmental conditions and increasing exposure to natural hazards due to population growth and urbanisation has been traditionally recognized in the literature (e.g. Brunsden and Thornes, 1979; Hufschmidt et al., 2005; Fuchs et al., 2013; Klose et al., 2015). In this study area, the population grew 4.3 times between 1869 and 2011. In the largest centre (Ústí nad Labem), this growth was represented by an increase of the urbanised area in the Q100 flood zone of the Labe (Elbe) River by approximately 200 ha. In contrast to growing exposure resulting from urbanisation, the role that adoption of new reduction strategies plays in vulnerability change through time is less addressed.

Two examples can be presented in order to illustrate the influences that social and technological development have on vulnerability. Firstly, significant changes in the factors underlying vulnerability to natural hazards are related to legislation. With respect to flood risks, for example, the first attempt to limit construction activities in flood-prone areas through territorial planning tools is registered in 1976 in Czechoslovakia. The law (Act 50/1976) noted that the function of an area may be changed following flood impacts (i.e. ex-post changes). Only lately, in Act No. 135/2001 and Act No. 183/2006, have preventive measures been included in territorial planning; thus, growing exposure to floods due to urbanisation was rigorously reflected in legislation only in the last two decades. The second example is that the increasing technical requirements of buildings have changed the vulnerability to particular natural hazards significantly. While the first lightning conductor was installed in the 1770s in Czech Lands, it only became widely adopted with new technical norms published in 1950s. During the $19^{\text {th }}$ century, lightning thus still represented the most frequent threat to most households, but it does not cause any remarkable risks at the present.

\begin{tabular}{|c|c|c|c|c|}
\hline Database & Highest frequency & $\begin{array}{l}\text { Highest number } \\
\text { of fatalities }\end{array}$ & $\begin{array}{l}\text { Highest economic } \\
\text { impacts }\end{array}$ & Highest insured losses \\
\hline $\begin{array}{l}\text { Historical hazards } \\
\text { in this study (1856-1902) }\end{array}$ & rainstorm with lightning & lightning & flood & Not known \\
\hline $\begin{array}{l}\text { Current hazards } \\
\text { (EM-DAT 1993-2016) }\end{array}$ & riverine flood & climatological (heat wave) & flood & meteorological (hailstorm) \\
\hline $\begin{array}{l}\text { Current hazards } \\
\text { (EEA 1998-2009) }\end{array}$ & meteorological (storm) & climatological (heat wave) & meteorological (storm) & meteorological (storm) \\
\hline
\end{tabular}

Tab. 4: Comparison of historical (this study) and current (Guha-Sapir et al., 2016, for the Czech Republic; EEA, 2010) natural hazards with the highest social and economic impacts

Sources: authors' compilation (this study); EM-DAT (Guha-Sapir et al., 2016); current hazards (EEA, 2010)

Finally, the homogeneity of the time-series is influenced by the very definition of natural hazards in different time periods. The most obvious difference between historical and current understandings of hazards lies in the current extension of meanings to include slow-onset hazards. Most profoundly, climatic hazards such as heat and cold waves currently represent the major events with extensive direct impacts on populations (e.g. EEA, 2010). In contrast, if reported in the past, they were described mainly in terms of their agricultural impacts and were not considered a hazard or disaster. For this reason, we argue for further research devoted to changes in vulnerability based on multi-hazard databases.

\section{Conclusions}

The present research has pointed out the bias resulting from the use of time-series to assess long-term changes in social vulnerability to natural hazards, as well as from the use of such assessments as a rationale for the design of new risk reduction strategies and scenarios. First, we reconstructed the social impacts of multiple natural hazards on a historical community in North Bohemia. Using the local newspapers, a total of 275 records reporting 599 hazard events were found and were assessed in terms of their relative direct damage, and classified according to their frequency and social impacts. The highest relative direct impacts were reconstructed for rainstorms and lightning, which can be contrasted to current statistics (highest impacts by floods, heat waves, hailstorms), which illustrates the changing nature of social vulnerability to natural hazards through time.
Second, the implications of multi-hazard databases and time-series for vulnerability studies were discussed. Our main findings relate to possible non-homogeneities in multi-hazard time-series, which are caused by two principal factors: (i) lack of standardisation in reporting the hazard events (partly emerging from the combination of documentary data of very different types); and (ii) social and technological factors underlying the social impacts of various hazards in individual historical periods. While the first factor emphasises the bias caused by the varying quality and changing availability of documentary data through time, the second points to the limited representativeness of long-term vulnerability assessment if researchers do not take into account the role of urbanisation, social and technological conditions (expressed by legislation and technical norms), as well as understandings of what poses as a hazard as proclaimed through risk reduction policies. In this respect, our findings call for a broadening of interdisciplinary approaches in the evaluation of currently established time-series of natural hazards, so that they can be used to support the decisions on design and adoption of new risk reduction strategies.

\section{Acknowledgments}

This research was supported by project No. GA16-02521S: "Individual and organizational decision-making in environmental risk reduction: determinants, motivations and efficiency", the Grant Agency of the Czech Republic. Two anonymous reviewers and Prof. Greer-Wootten, the journal's editor-in-chief are acknowledged for providing important suggestions to improve the manuscript. 


\section{References:}

ACETO, L., CALOIERO, T., PASQUA, A. A., PETRUCCI, O. (2016): Analysis of damaging hydrogeological events in a Mediterranean region (Calabria). Journal of Hydrology. Doi:10.1016/j.jhydrol.2015.12.041

ADGER, W. N. (2000): Social and ecological resilience: are they related? Progress in Human Geography, 24: 347-364.

ARGYRIS, C., SCHÖN, D. (1978): Organizational learning: A theory of action perspective. Addison Wesley, Reading.

AUSSIGER ANZEIGER (1856-1902): Archive of the Ústí nad Labem Town.

BATESON, G. (1972): Steps to an ecology of mind. Collected essays in anthropology, psychiatry, evolution, and epistemology. London, Intertext Books.

BÍL, M., KREJČÍ, O., BÍLOVÁ, M., KUBEČEK, J., SEDONÍK, J., KREJČÍ, V. (2014): A Chronology of landsliding and its impacts on the village of Halenkovice, Outer Western Carpathians. Geografie, 119: 342-363.

BRANDSTRÖM, A., KUIPERS, S., DALÉUS, P. (2008): The politics of tsunami responses: comparing patterns of blame management in Scandinavia. In: Boin, A., McConnell, T., Hart, P. [eds.]: Governing after crisis (pp. 114-147). Cambridge, Cambridge University Press.

BRÁZDIL, R. (2006): Historical and reent floods in the Czech Republic: causes, seasonality, trends, impacts. In: Schanze, J., Zeman, E., Maršálek, J. [eds.]: Flood Risk Management: Hazards, Vulnerability and Mitigation Measures (pp. 247-259). Berlin-Heidelberg, Springer Verlag.

BRÁZDIL, R. (2009): Historical climatology and its contribution to climate reconstruction in Europe. In: Nachhaltige Geschichte (pp. 65-89). Zurich, Chronos Verlag.

BRÁZDIL， R., ĽEZNÍČKOVÁ, L., HAVLÍČEK, M., ELLEDER, L. (2012): Floods in the Czech Republic. In: Kundzewicz, Z. [ed.]: Changes in Flood Risk in Europe (pp. 178-198). IAHS Special Publication 10, Wallingford (UK).

BRUNSDEN, D., THORNES, J. B. (1979): Landscape sensitivity and change, The Institute of British Geographers, Transactions, New Series, 4: 436-484.

BURKE, P. (2005): History and social theory. Cambridge, Polity Press.

BURTON， I., KATES， R.W., WHITE， G. F. (1978): The environment as hazard. New York, Oxford University Press.

CALOIERO, T., PASQUA, A. A., PETRUCCI, O. (2014): Damaging Hydrogeological Events: a procedure for the assessment of severity levels and an Application to Calabria (Southern Italy). Water, 6: 3652-3670.

CROZIER, M. J., GLADE, T. (1999): Frequency and magnitude of landsliding: fundamental research issues. Zeitschrift für Geomorphologie, 115 (Suppl.-Bd.): 141-155.

CUTTER, S. (1993): Living with risk. London, Edward Arnold.

CUTTER, S. (1996): Vulnerability to environmental hazards. Progress in Human Geography, 20: 529-539.

DILLEY, M., GRASSO, V. F. (2016): Disaster reduction, loss and damage data, and the post-2015 international policy agenda. Environmental Science \& Policy, 61: 74-76.
DOLÁK, L., BRÁZDIL, R., VALÁŠEK, H. (2015): Impacts of hydrometeorological extremes in the BohemianMoravian Highlands in 1706-1889 as derived from taxation records. Geografie, 120: 465-488.

EEA (2010): Mapping the impacts of natural hazards and technological accidents in Europe. Copenhagen, European Environmental Agency.

ELLIOT, A. H., KIRSCHBAUM, M. J. (2007): The preliminary landslide history database of Utah, 18501978. Utah Geological Survey, Salt Lake City, Utah.

FUCHS, S., KEILER, M., SOKRATOV, S., SHNYPARKOV, A. (2013): Spatiotemporal dynamics: the need for an innovative approach in mountain hazard risk management. Natural Hazards, 68: 1217-1241.

GLADE, T., ALBINI, P., FRANCES, F. [eds.] (2001): The Use of Historical Data in Natural Hazard Assessments. Dordrecht, Kluwer.

GLASER,R.,RIEMANN,D.,SCHÖNBEIN,J.,BARRIENDOS, M., BRÁZDIL, R., ... \& HIMMELSBACH, I. (2010): The variability of European floods since AD 1500. Climatic Change, 101: 235-256.

GUHA-SAPIR, D., BELOW, R., HOYOIS, P. (2016): EM-DAT: The CRED/OFDA International Disaster Database - www.emdat.be - Université Catholique de Louvain, Brussels.

GUZZETTI, F., CARDINALI, M., REICHENBACH, P. (1994): The AVI Project: A bibliographical and archive inventory of landslides and floods in Italy. Environmental Management, 18: 623-633.

HEWITT, K. (1983): Interpretations of calamity from the viewpoint of human ecology. London, Allen and Unwin.

HUFSCHMIDT, G., CROZIER, M., GLADE, T. (2005): Evolution of natural risk: research framework and perspectives. Natural Hazards and Earth System Sciences, 5: 375-387.

HUFSCHMIDT, G. (2011): A comparative analysis of several vulnerability concepts. Natural Hazards, 58: 621-643.

IBSEN, M. L., BRUNSDEN, D. (1996): The nature, use and problems of historical archives for the temporal occurrence of landslides, with specific reference to the south coast of Britain, Ventnor, Isle of Wight. Geomorphology, 15: 241-258.

KATES, R. W., WOHLWILL, J. [eds.] (1966): Man's Response to the Physical Environment. Journal of Social Issues, 22: $15-20$.

KLIMEŠ, J. (2011): Rockfall hazard and risk assessment on forested slopes, examples from Czechia. Geografie, 116: $144-155$.

KLOSE, M., DAMM, B., HIGHLAND, L. M. (2015): Databases in geohazard science: An introduction. Geomorphology, 249: $1-3$.

KLOSE, M., MAURISCHAT, P., DAMM, B. (2016): Landslide impacts in Germany: A historical and socioeconomic perspective. Landslides, 13: 183-199.

LEI, Y., WANG, J., YUE, Y., ZHOU, H., YIN, W. (2014): Rethinking the relationships of vulnerability, resilience, and adaptation from a disaster risk perspective. Natural Hazards, 70: 609-627. 
MCCOMBS, M., SHAW, D. (1972): The agenda-setting function of mass media. Public Opinion Quarterly, 36: 176-184.

MINÁŘOVÁ, J., MÜLLER, M., HÄNSEL, S., MATSCHULLAT, J., CLAPPIER, A. (2015): Heavy precipitation in mid-elevation mountain systems in Central Europe: case study of the Krušné hory/Erzgebirge (Czech Republic, Germany). In: $15^{\text {th }}$ EMS Annual Meeting \& $12^{\text {th }}$ European Conference on Applications of Meteorology (ECAM).

PFISTER, C. (2009): Learning from natural-induced disasters: theoretical considerations and case studies from Western Europe. In: Mauch, C., Pfister, C. [eds.]: Natural disasters, cultural responses (pp. 17-40). Plymouth, Lexington Books.

PFISTER, C., BRÁZDIL, R. (2006): Social vulnerability to climate in the "Little Ice Age": an example from Central Europe in the early 1770s. Climate of the Past, 2: 115-129.

PFISTER, C., LUTERBACHER, J., WANNER, H., WHEELER, D., BRÁZDIL, R.,... \& DEL PRIETO, M. R. (2008): Documentary evidence as climate proxies. White Paper written for the Proxy Uncertainty Workshop in Trieste, 9-11 June 2008.

RAŠKA, P., ZÁBRANSKÝ, V., DUBIŠAR, J., KADLEC, A., HRBÁČ́OVÁ, A., STRNAD, T. (2014): Documentary proxies and interdisciplinary research on historic geomorphologic hazards: a discussion of the current state from a central European perspective. Natural Hazards, 70: 705-732.

RAŠKA, P., KLIMEŠ, J., DUBIŠAR, J. (2015): Using local archive sources to reconstruct historical landslide occurrence in selected urban regions of the Czech Republic: examples from regions with different historical development. Land Degradation and Development, 26: 142-157.
RAŠKA, P., BRÁZDIL, R. (2015): Participatory responses to historical flash floods and their relevance for current risk reduction: a view from a postcommunist country. Area, 47: 166-178.

RYBÁŘ, J., VILÍMEK, V., CÍLEK, V. (2000b): Process analysis of deep slope failures in České středohoří neovolcanites. Acta Montana, Ser. AB: 115(8): 39-46.

SALVATI, P., BIANCHI, C., ROSSI, M., GUZZETTI, F. (2010): Societal landslide and flood risk in Italy. Natural Hazards Earth System Sciences, 10: 465-483.

SAREWITZ, D., PIELKE, R. Jr., KEYKHAH, M. (2003): Vulnerability and risk: some thoughts from a political and policy perspective. Risk Analysis, 23: 805-810.

SEN, A. (1981): Famines and poverty. London, Clarendon Press.

TROPEANO, D., TURCONI, L. (2004): Using historical documents for landslide, debris flow and stream flood prevention. Applications in Northern Italy. Natural Hazards, 31: 663-679.

VOSS, M., WAGNER, K. (2010): Learning from (small) disasters. Natural Hazards, 55: 657-669.

WANNER, H., BECK, C., BRÁZDIL, R., CASTY, C., DEUTSCH, M., ... \& XOPLAKI, E. (2004): Dynamic and socioeconomic aspects of historical floods in Central Europe. Erdkunde, 58: 1-16.

WHITE, G. F. (1936): The limit of economic justification for flood protection. The Journal of Land and Public Utility Economics, 12: 133-148.

WHITE, G. F. (1942): Human adjustments to floods. Unpublished PhD, Department of Geography, University of Chicago.

WISNER, B., BLAIKIE, P., CANNON, T., DAVIS, I. (2004): At risk - natural hazards, people's vulnerability and disasters. London, Routledge.

\section{Please cite this article as:}

RAŠKA, P., DUBIŠAR, J. (2017): Impacts of natural hazards on an early industrial community: A case study of North Bohemia and its implications for long-term vulnerability assessment. Moravian Geographical Reports, 25(1): 13-23. Doi: 10.1515/mgr-2017-0002. 